\title{
Venture-kapitaal in de Verenigde Staten
}

\author{
Is hier lering voor Nederland?
}

\section{Inleiding}

Venture capital in de Verenigde Staten is een interessant verschijnsel. Het is dat voor de Amerikanen zelf, maar ook voor ons Nederlanders. Menigeen zal zich afvragen wat daarvan de relevantie kan zijn voor een land als het onze, met een zo geheel ander maatschappelijk klimaat. Inderdaad is alleen reeds de centrale plaats die het winstmotief inneemt in Noord-Amerika zo sterk afwijkend van de plaats die het heeft in ons sociaal denken en voelen, dat het een hachelijke zaak lijkt om een stukje Amerikaanse kapitaalmarkt te beschrijven met het dubbele oogmerk van objectieve rapportage en exemplaire beeldvorming. De verschillen tussen Noord-Amerika en WestEuropa werden voor het eerst breed uitgemeten aan het eind van de dertiger jaren der vorige eeuw door Alexis de Tocqueville in zijn bekende werk 'De la démocratie en Amerique'. Over het belangrijke punt van de maatschappelijke rol van de winst merkte hij op, dat in brede kringen in Europa nog de typisch aristocratische instelling leeft, dat men werken weliswaar niet schuwt, maar wel het werken om winst: 'le travail est glorieux quand c'est l'ambition ou la seule vertu qui le fait entreprendre'. In Amerika zien wij volgens hem de ideeën van werk en winst steeds verenigd.

Er is sindsdien over het winstmotief veel geschreven door economen, filosofen en sociologen. Wat daar ook van zij, zeker is dat in West-Europa ook degenen die de ondernemingsgewijze productie en het winstmotief aanvaarden, tevens met zich mee blijven dragen de traditie van vele eeuwen maatschappelijke ontwikkeling, met verworvenheden die niet door winst zijn verkregen of door winst in stand moeten worden gehouden. Het blijft een voortdurend zoeken naar evenwicht tussen collectieve voorzieningen en individuele werkzaamheid, tussen te gerede aanvaarding van centrale bescherming en te ongebreideld streven naar winst. In tijden zoals wij die nu beleven, heeft het zijn nut om bij het zoeken naar dat evenwicht lering te trekken bijvoorbeeld uit ontwikkelingen in de Verenigde Staten. Ook daar is sprake van een maatschappij in voortdurende beweging, op zoek naar dat evenwicht. Uiteraard ligt dit in vele gevallen op een ander niveau, bepaald door andere tradities dan die van Europese landen, maar veelal is dit meer een kwestie van maat dan van wezenlijk verschil. Om die reden zijn ontwikkelingen in Amerika, zoals die van venture-kapitaal, voor ons altijd leerzaam en soms zelfs vatbaar voor profijtelijke navolging. In het hiernavolgende zal worden getracht de venture-kapitaalmarkt in de Ver- 
enigde Staten te beschrijven aan de hand van aspecten die geacht kunnen worden enige relevantie te hebben voor het economisch gebeuren in ons land. Schrijver dezes heeft daarbij gebruik gemaakt in de eerste plaats van basismateriaal te vinden in de maandelijkse uitgave 'Venture Capital Journal' van Capital Publishing Corporation, Wellesly Hills, Massachusetts, en in de tweede plaats van de informaties en documenten die hij heeft kunnen vergaren bij zijn contacten in de Verenigde Staten met overheid en met vooraanstaande vertegenwoordigers van de desbetreffende bedrijfstak.

\section{Beginfasen-financiering}

Het Amerikaanse venture-kapitaal onderscheidt zich in menig opzicht van andere kapitaalvormen, maar het belangrijkste kenmerk waardoor het zich van die andere kapitaalvormen onderscheidt is het aangepast zijn aan éen der beginfasen van een onderneming. Oorspronkelijk betrof venture-kapitaal de financiering van het prille begin van de onderneming, maar met de groei van de bedrijfstak van venture-kapitaal na de zestiger jaren is het venture-kapitaal zich mede gaan richten op de vervolgstadia van het gehele proces van ontplooiïng van de onderneming tot volle wasdom. Het heeft echter daarbij steeds zijn hoofdeigenschappen behouden, welke als volgt kunnen worden samengevat:

$a$. het financieringsinstrument is risicodragend (aandelen, zowel gewone als convertibel prefente, achtergestelde leningen met conversie-recht of warrants en voorts andere risicodragende combinaties);

$b$. het risico-element is relatief groot, doordat de investering niet geënt is op een bestaand bedrijf, maar op een nieuwe onderneming, waarvan ondernemer en produkt zichzelf nog moeten bewijzen;

c. het verwacht rendement is relatief hoog, maar kan eerst na vier a acht jaar worden gerealiseerd en wel in de vorm van vermogensappreciatie bij verkoop van de investering aan derden;

$d$. de ontwikkeling van de nieuwe onderneming gaat gepaard met blijvende betrokkenheid en management-steun van de investeerder.

Op deze aspecten komen wij hieronder nader terug, maar daaraan voorafgaand zijn enkele opmerkingen op hun plaats terzake van het wezenskenmerk van venture-kapitaal, de beginfasenfinanciering. Deze financiering is gericht op, en aangepast aan, een der fasen uit de beginperiode van de onderneming, te weten de startfase en de eerste expansiefase. In 1982 betrof $45 \%$ van de venture-investeringen de startfase en $44 \%$ de eerste expansiefase. De overige $11 \%$ had betrekking op venture-financiering voor bijzondere situaties bij reeds bestaande ondernemingen: zgn. turn-around-investeringen, waar nieuw management wordt binnengebracht ter sanering van de onderneming en zgn. leveraged buy-outs, waar een management-team in staat wordt gesteld een deel van een onderneming te kopen, doorgaans door uitkoop van bestaande aandeelhouders. In de startfase en de eerste expansiefase verkeert de onderneming nog niet in een winstgevende positie. Hiervan is eerst sprake in de tweede expansiefase. Vóór de opkomst van de venture-kapitaalbranche was men wat de eerste stadia betreft bijna uitsluitend aangewezen op geld van familieleden, vrienden en kennissen, die 
Tabel 1 Levenscyclus van een nieuwe onderneming (Amerikaanse marktsituatie anno 1977)*

\begin{tabular}{|c|c|c|c|c|c|c|}
\hline $\begin{array}{l}\text { Fasen } \\
\text { Omzet }(\mathrm{m} \ln \$)\end{array}$ & $\begin{array}{l}\text { Onderzoek } \\
\text { Geen }\end{array}$ & $\begin{array}{l}\text { Start } \\
0-2 \\
\end{array}$ & $\begin{array}{l}\text { le expansie } \\
2-10\end{array}$ & $\begin{array}{l}2 e \text { expansie } \\
10-25\end{array}$ & $\begin{array}{l}\text { Volwassenwording } \\
25-40\end{array}$ & $\begin{array}{l}\text { Voluassenheid } \\
40 \text { en hoger }\end{array}$ \\
\hline $\begin{array}{l}\text { Winst } \\
(\mathrm{m} \ln \$)\end{array}$ & $\begin{array}{l}7 \\
7 \\
6 \\
5 \\
4 \\
3 \\
2 \\
1 \\
\end{array}$ & & & & & \\
\hline $\begin{array}{l}\text { Verlies } \\
(\mathrm{m} \ln \$)\end{array}$ & $\begin{array}{l}1 \\
2 \\
3 \\
4 \\
5 \\
6\end{array}$ & & at & & $\begin{array}{l}\text { umulatief } \\
\text { arresultaat }\end{array}$ & \\
\hline $\begin{array}{l}\text { Kapitalisatie } \\
\text { Lengte van } \\
\text { fasen (jaren) }\end{array}$ & $\begin{array}{l}\$ 5000-\$ 1 \mathrm{mln} \\
1-5\end{array}$ & $\begin{array}{l}\$ 0,5-\$ 2,5 \mathrm{~m} / \mathrm{n} \\
1-3\end{array}$ & $\begin{array}{l}\$ 2-6 \mathrm{mln} \\
2-3\end{array}$ & $\begin{array}{l}\$ 6-15 \mathrm{~min} \\
3-4\end{array}$ & $\begin{array}{l}\$ 15-30 \mathrm{~m} \ln \\
2-5\end{array}$ & $\begin{array}{l}\$ 30 \mathrm{~m} \ln \\
--\end{array}$ \\
\hline $\begin{array}{l}\text { Management en } \\
\text { organisatie } \\
\text { Financiering } \\
\text { met eigen } \\
\text { vermogen: } \\
\text { aantal } \\
\text { gembedrag } \\
\text { bron }\end{array}$ & $\begin{array}{l}\text { Oprichter; } \\
\text { geen organisatie } \\
\\
\\
2-3 \\
\$ 100.000 \\
\text { Onderhands }\end{array}$ & $\begin{array}{l}\text { Oprichter en } \\
\text { compagnons; zeer } \\
\text { losse organisatie }\end{array}$ & $\begin{array}{l}\text { Oprichter of pro- } \\
\text { fessionele manager; } \\
\text { ontstaan van for- } \\
\text { mele organisatie } \\
\\
2-3 \\
\$ 1,5 \mathrm{mln} \\
\text { Onderhands }\end{array}$ & $\begin{array}{l}\begin{array}{l}\text { Oprichter of pro- } \\
\text { fessionele manager; } \\
\text { formele organisatie }\end{array} \\
1 \\
\$ 7,5 \mathrm{mln} \\
\text { Openbaar of on- } \\
\text { derhands met } \\
\text { voorrang }\end{array}$ & $\begin{array}{l}\text { Professionele } \\
\text { managers; complexe } \\
\text { organisatie }\end{array}$ & $\begin{array}{l}\text { Complexe organi- } \\
\text { satie met ver- } \\
\text { schillende niveaux } \\
\text { van management } \\
\text { Verscheidenheid } \\
\text { van bronnen }\end{array}$ \\
\hline
\end{tabular}

* Bewerking van tabel uit: Report of the SBA Task Force on Venture and Equity Capital for Small Business, 1977.

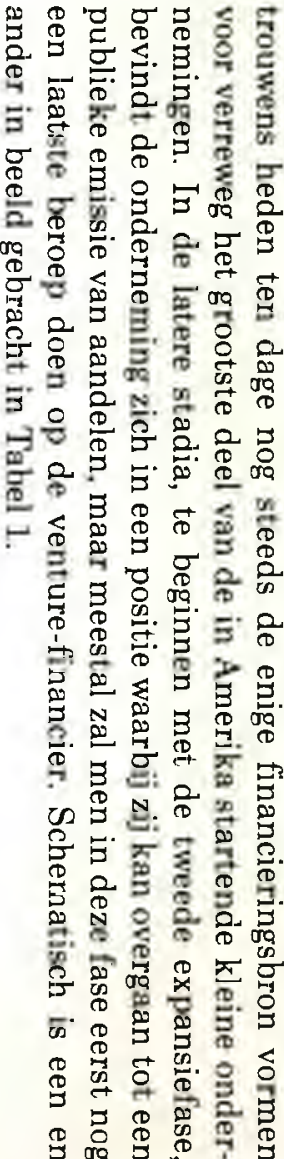




\section{Bijdrage aan de nationale economie}

Dat voor startende of jonge ondernemingen, die voor enig beroep op de conventionele financieringsinstellingen nog onvoldoende zekerheden kunnen verschaffen en ook nog geen gerealiseerde winsten kunnen tonen, een eigen venture-kapitaalmarkt bestaat, kan voor de economie van het land een groot goed zijn. Naarmate dit proces van kapitaalverschaffing beter en op grotere schaal functioneert, zal de bijdrage daarvan aan het nationaal produkt groter zijn. De venture-kapitaalbranche in de Verenigde Staten is als branche eigenlijk pas in 1958 van de grond gekomen en tot grote bloei gekomen na 1977. Het is uitermate moeilijk in cijfers bij benadering aan te geven wat deze branche in de kwart eeuw van haar bestaan aan de Amerikaanse economie heeft bijgedragen. Bij wijze van ruwe benadering zou men echter het volgende kunnen stellen. De venture-kapitaalbranche heeft de laatste tien jaren in portfolio-ondernemingen (ondernemingen in de aandelenportefeuille van venture capital-fondsen) een bedrag gestoken van ca. $\$ 7,5$ miljard, welk bedrag, gezien de ervaring met de bedrijfstak over een lange reeks van jaren, zichzelf na de beginfase der betrokken ondernemingen vijf maal zal hebben terugverdiend. Bij het afscheid van de branche na ongeveer zeven jaar, hebben de portfolio-ondernemingen derhalve een marktwaarde van $\$ 37,5$ miljard. Het is geenszins een boute veronderstelling dat dit bedrag in de rijpe levensfase van die ondernemingen zich nog eens twee a drie maal vermenigvuldigt. Dat maakt dat de investering van de venturebranche van de laatste tien jaar aan de totale marktwaarde van het Amerikaanse bedrijfsleven een bedrag toevoegt van minstens $\$ 100$ miljard. Dit is, om een vergelijking in ons meer vertrouwde proporties te maken, ongeveer vijf maal de beurswaarde van alle Nederlandse aandelen tezamen. Daarnaast zijn er indirecte bijdragen van de werkzaamheid der venturekapitaalbranche, zoals het ontstaan, de groei en de instandhouding van het netwerk rond de venture-gesteunde ondernemingen van toeleverende bedrijven en bedrijfjes.

Een ander indirect, maar wel direct waarneembaar, positief effect is voorts de bevordering van de algemene productiviteit der nationale economie. In een rapport van de General Accounting Office, aangeboden aan het Joint Economic Committee van het Congres op 12 augustus 1982, wijst deze dienst op de grote bijdrage van de venture-branche aan de nationale economie. Zij baseert zich daarbij op gegevens van 1332 ondernemingen, waarin de venture-kapitaalbranche in de periode van 1970-1979 een totaal bedrag investeerde van $\$ 1,4$ miljard. De conclusies - gedeeltelijk op grond van meer gedetailleerde gegevens van de 72 (der 1332) ondernemingen wier aandelen op de beurs genoteerd zijn - komen hier op neer, dat de beginfasefinanciering van $\$ 1,4$ miljard leidt tot een steeds groeiende verkoopomzet in de tachtiger jaren, welke omzet in 1989, als al die venture-gesteunde ondernemingen in de volwassen leeftijd zijn aangeland, een bedrag zal belopen van circa $\$ 88$ miljard per jaar, ofwel zestig maal de venture-kapitaalinvestering. Aangezien $61 \%$ van deze investering is gegaan naar ondernemingen die productiviteitsbevorderende diensten en goederen leveren, is het duidelijk dat ook de indirecte bijdrage van de venture-kapitaalbranche voor 
de nationale economie in de Verenigde Staten van bijzonder grote betekenis is.

\section{Functie en plaats van de bedrijfstak}

Het proces van venture-kapitaalverschaffing wordt georganiseerd door een kleine groep van gespecialiseerde ondernemingen, een groep die zich na de oorlog geleidelijk heeft gevormd en thans is uitgegroeid tot een afzonderlijke bedrijfstak met eigen instituties en gewoonten en een goed georganiseerde vertegenwoordigende organisatie, de National Venture Capital Association in Washington D.C. De ontstaansgeschiedenis van deze bedrijfstak is een leerzaam stukje economische historie en om die reden zal daar thans iets nader op worden ingegaan.

Venture-kapitaal hebben de Verenigde Staten altijd al gekend. Het ging daarbij steeds om geld van vermogende particulieren, van syndicaten georganiseerd door investment bankers en geld van familie-organisaties die daarvoor een professionele manager aantrokken. Maar de grondslag voor de institutionalisering van het proces van venture-kapitaalverschaffing werd eerst gelegd in 1946 met de oprichting van de American Research and Development Corporation (ARD) in Boston en de echte ontplooiing zette pas in met de inwerkingtreding van de Small Business Investment Act van 1958. Op basis van die wet werden Small Business Investment Companies (SBIC's) opgericht. Via deze verkreeg men belastingfaciliteiten en de mogelijkheid van het opnemen op gunstige voorwaarden van leningen bij de overheid tot een veelvoud van drie of vier van het eigen kapitaal van de SBIC's. In enkele jaren waren reeds meer dan 700 van deze instellingen opgericht. Echter, door onervarenheid, oriëntering op te korte termijn en te sterke en ondeskundige overheidsbemoeienis liep het grootste deel op een mislukking uit en binnen tien jaar waren er nog slechts 248 SBIC's over. Niettemin had het instituut van SBIC's de belangstelling voor venturefinanciering sterk aangewakkerd. Zo was intussen de groep van vermogende particulieren en families aangegroeid met gespecialiseerde venture capitalfirma's. Oorspronkelijk kwamen deze voort uit de kring van investment bankers, later in de zeventiger jaren uit het initiatief van professionele managers. Deze gehele groep tezamen vormt thans de eigenlijke kern van de bedrijfstak. Meestal gaat het hier om professionele venture capitalmanagers die kapitaal van derden onderbrengen in een venture capitalfonds. Dit fonds heeft doorgaans de rechtsvorm van een limited partnership, waarvan die managers zelf de general partners zijn - vergelijkbaar met de beherende vennoten van onze commanditaire vennootschap -. Zij brengen het fondskapitaal bijeen door onderhandse plaatsing bij vermogende particulieren en institutionele beleggers. De grootte van zulke fondsen varieert tussen $\$ 20$ en $\$ 60$ mln (met slechts enkele uitschieters van meer dan $\$ 100 \mathrm{mln}$ ), bedragen die thans twee à drie maal zo hoog zijn als in de zestiger en in het begin van de zeventiger jaren. De partnerships worden gevormd voor een beperkte periode van tien tot twaalf jaren, de tijd die nodig is voor het investeren van de gelden en het laten rijpen van de investeringsobjecten. 
Naast de zojuist beschreven grote groep van venture-kapitaalfirma's is er de groep van SBIC's en tenslotte is er een derde groep, die van dochtermaatschappijen van grote ondernemingen zoals Citicorp, Xerox, Exxon en General Electric.

Tabel 2

Samenstelling bedrijfstak (eind 1982)

Aantal

180

360

SBIC's

Dochtermaatschappijen van

- financiële instellingen

- industriële maatschappijen

Onafhankelijke ondernemingen van:

- grote vermogensbezitters met eigen venturefondsen

- professionele managers van gemeenschap-

pelijke fondsen van derden
Beschikbaar gesteld

vermogen (in mrd. \$)

\section{.}


De spectaculaire groei begon in 1978, nadat vanaf 1972 het beschikbaar vermogen, de 'venture capital pool', practisch stationair was gebleven rond het niveau van $\$ 2,5$ a $\$ 3$ miljard. In die tijd bleef niettemin het investeren in portfolio-ondernemingen doorgaan op het niveau van circa $\$ 400$ miljoen per jaar en wel voornamelijk door recycling van gelden vrijgekomen door de verkoop van pool-investeringen uit vroegere jaren. Het bedrag dat de venture-pool investeert per portfolio-onderneming is geleidelijk gegroeid. Gemiddeld bedroeg dit in de jaren 1970-78 \$1 miljoen, sindsdien is dit gemiddelde gegroeid naar ca. $\$ 13 / 4$ miljoen. Waar de investeringsgelden naar toe gingen blijkt uit de volgende tabel.

Tabel 4

Venture-investeringen naar soort van bedrïven

(Amerikaanse indeling en nomenclatuur is aangehouden)

\begin{tabular}{lcc}
\hline & 1981 in $\%$ & 1982 in $\%$ \\
\hline Communications & 11 & 10 \\
Computer related & 30 & 42 \\
Other electronics related & 12 & 14 \\
Genetic engineering & 7 & 3 \\
Medical/Health related & 6 & 6 \\
Energy & 10 & 6 \\
Industrial automation & 4 & 3 \\
Industrial products & 5 & 4 \\
Consumer related & 5 & 5 \\
Other & 10 & 7 \\
& 100 & 100 \\
\hline
\end{tabular}

De toegenomen relatieve betekenis van de eigenlijke kern van de bedrijfstak, de onafhankelijke ondernemingen, wordt geïllustreerd door het toegenomen percentage dat deze groep inneemt in de totale venture capital-pool, dat van $37 \%$ per eind 1979 opliep tot $52 \%$ per eind 1982 . Die toegenomen betekenis blijkt ook uit het aandeel dat de groep van onafhankelijke ondernemingen inneemt in het nieuwe kapitaal dat de drie groepen in totaal jaarlijks aantrekken: dit steeg van ca. $50 \%$ in '79 naar ca. $80 \%$ in 1982.

\section{Groei-impulsen}

De opeenvolging van dieptepunten en perioden van verhoogde activiteit leert veel over de aard van de bedrijfstak en over de factoren die haar groei hebben beïnvloed. Zij is opgekomen door drie onderscheiden externe impulsen en zij heeft derhalve als het ware bij de geboorte meegekregen een sterke gevoeligheid voor invloeden van buiten. De eerste impuls aan het einde van de vijftiger jaren kwam voort uit de gunstige omstandigheden die de wetgever had geschapen met het SBIC-programma. Dit was het overenthousiaste begin dat spoedig verliep. Het einde der zestiger jaren bracht de tweede impuls in een tijd van euforie toen de Dow Jones-index de 1000 gepasseerd was en het er op leek dat openbare emissies van jonge ondernemingen van succes verzekerd waren als maar iets van 'tronics' in de naam voorkwam. Ook dit kwam tot een vrij spoedig einde, gedeeltelijk als gevolg 
van de doorwerking van de Tax Reform Act van 1969 en gedeeltelijk als gevolg van de eind 1972 ingezette recessie. Genoemde act markeerde het begin van een serie verhogingen van de capital gains tax die in de periode van 1969 tot 1976 deze belasting geleidelijk opvoerde van $24 \%$ naar $49 \%$. In die periode droogde de stroom van nieuw kapitaal naar de bedrijfstak bijna geheel op, zoals ook het aantal van openbare aandelenemissies van kleinere ondernemingen van een hoogtepunt van 698 in 1969 geleidelijk tot ongeveer het nulpunt daalde.

Thans beleven wij de derde impuls. Vanaf 1978 is een toenemende stroom van kapitaal geleid naar de venture-kapitaal-markt als gevolg van de volgende oorzaken:

- de venturefinancieringen uit het begin der zeventiger jaren en later zijn intussen tot wasdom gekomen. Velen bleken successen, sommigen zelfs zeer grote successen, zoals Amdahl, Tandem Computers, Federal Express, Apple Computer, e.a. en die spreken tot de verbeelding;

- in 1978 werd de capital gains tax weer verminderd van $49 \%$ naar $28 \%$, een grote stimulans voor de venture-financier die het van vermogenswinst op zijn investeringen moet hebben en niet van de jaarlijkse opbrengsten daarvan;

- daarop volgde de versoepeling van de SEC-bepalingen terzake van de veplichte registratie, door de kleinere onderneming, van openbare emissies of van onderhandse verkopen van pakketten aandelen in haar onderneming;

- tenslotte werd in 1980 het investeringsklimaat verder verbeterd doordat venture-investeringen onder de ERISA-bepalingen (Employment Retirement Income Security Act van 1974) niet langer waren uitgesloten voor pensioenfondsen.

Van al deze factoren is ongetwijfeld de belangrijkste geweest het verlagen van de capital gains tax. Het is, wat de lering voor Nederland betreft, daarbij niet zo relevant dat wij in ons land niet een dergelijke belasting kennen, maar wel de omstandigheid dat het in belangrijke mate te danken was aan één welgekozen belastingsfaciliteit dat

$a$. kapitaalaanbieders zich met enthousiasme hebben gestort op nieuwe ondernemingen en

$b$. personen met ondernemersgeest werden gestimuleerd zaken te ondernemen omdat zij wisten, dat zij er gerede steun voor zouden kunnen vinden bij een gespecialiseerde branch voor de verschaffing van venturekapitaal.

De belastingfaciliteit van 1978 in de vorm van een rigoreuze reductie van de capital gains tax, was gekoppeld aan succes. Het ging niet om een verliesgarantie, een vangnet voor het geval het mis gaat, maar om een premiëring die slechts genoten kan worden wanneer de portfolio-investering een succes is geworden en verkoop-rijp. Het is een premiëring gericht op het op gang brengen van een nieuwe onderneming, fiscaal-technisch direct geleid naar haar aandeelhouders, te weten de ondernemer van de portfolioonderneming en zijn venture-financiers. 
Uiteraard is het voorbeeld van de Amerikaanse capital gains tax in Nederland niet van toepassing, omdat wij die belasting hier niet kennen en het is zelfs de vraag of gezocht moet worden in de richting van een toekomstige belastingverlichting van de risico-investeerder, namelijk als deze t.z.t. zijn vermogenswinst realiseert. Men zou ook kunnen denken aan een onmiddellijke belastingverlichting ter gelegenheid van de investeringsuitgave, b.v. door het geheel of gedeeltelijk aftrekbaar maken voor inkomsten- of vennootschapsbelasting van de venture-financiering.

\section{Macro-economisch beeld}

De vraag is wel gesteld of in relatief even sterke mate als in de Verenigde Staten ook in Nederland venture-kapitaal beschikbaar zou kunnen komen als de aantrekkelijkheid daarvan zou worden gestimuleerd. Zou onze, door de overheidsvraag gedomineerde kapitaalmarkt, daar voldoende ruimte voor kunnen bieden? Daarvoor is het goed een blik te slaan op de volgende tabel.

\section{Tabel 5}

Venture-kapitaal en nationale besparingen

\begin{tabular}{lrrr}
\hline & 1969 & 1977 & 1981 \\
\hline $\begin{array}{l}\text { 1. Venture-investeringen in portfolio- } \\
\text { ondernemingen in de Verenigde Staten (mln \$) }\end{array}$ & ca 600 & 400 & 1,400 \\
$\begin{array}{l}\text { 2. Netto-nationale besparingen in de Verenigde } \\
\begin{array}{l}\text { Staten (mln \$) } \\
\text { Jenture-investeringen als percentage van } \\
\text { nationale besparingen in de Verenigde Staten }\end{array}\end{array}$ & 67,000 & 114,000 & 146,000 \\
$\begin{array}{l}\text { 4. Netto-nationale besparingen in Nederland } \\
\text { (mln glds) }\end{array}$ & 18,900 & $0,4 \%$ & $1,0 \%$ \\
$\begin{array}{l}\text { 5. Hypothetische venture-investeringen in } \\
\text { Nederland (bij toepassing van percentage } \\
\text { sub 3) }\end{array}$ & 170 & 145 & 34,600 \\
\hline
\end{tabular}

Tabel 5 illustreert voldoende, dat beschikbaarheid van financiële middelen in Nederland geen bottle-neck behoeft te zijn. Dat is ook niet te verwonderen, want het kenmerk van venture-kapitaal is juist dat met weinig venture-financiering kapitaal uit andere bronnen wordt aangezwengeld.

Wat in Nederland wel een bottle-neck is, is de afwezigheid van een rendementsverwachting zowel bij de potentiële ondernemer als bij de potentiële venture-investeerder. De onderlinge afhankelijkheid van deze twee vergroot nog het probleem. Zonder het bestaan van een gespecialiseerde venture capital-branche ontbreekt voor de jonge ondernemer de veelal onontbeerlijke promotor en begeleider. Hiermee zijn wij gekomen aan de laatste twee aspecten waaraan wij hier aandacht willen geven, t.w.:

- de werkwijze van de venture-kapitaalbranche

- het rendement van venture-kapitaal. 


\section{Werkwijze}

Het zou hier te ver voeren een min of meer systematisch overzicht te geven van de werkwijze die de venture-kapitaalbranche in het algemeen in de Verenigde Staten volgt. ${ }^{1}$ Het is echter van belang hier op twee aspecten te wijzen:

a. de kracht, en dus ook de beperking, van de venture-kapitaalbranche is de persoonlijke ondernemers-instelling van de beherende vennoten van de venture-kapitaalfondsen, de general partners van de limited partnerships. Niet alleen hadden zij, alvorens ze general partner werden, reeds geruime tijd venture-ervaring en dragen zij als general partners in belangrijke mate ertoe bij dat ventures worden gevonden en vervolgens gelanceerd. Zij hebben ook een groot eigen ondernemersbelang bij het venture-kapitaalfonds waarvan de winsten voor 20 à $25 \%$ aan hen zullen toevallen. Zij zetten zich persoonlijk in voor de onderneming waarin geïnvesteerd is, gedurende de gehele portefeuilleperiode, om de nog jonge onderneming te doen slagen. Doorgaans nemen zij ook zitting in de board van de desbetreffende onderneming als zij bij de kapitaalverschaffing lead-investor waren. Deze persoonlijke betrokkenheid, deze zgn. value added welke zij geven aan de portfolio-onderneming, is echter tevens de beperking. Per general partner kunnen niet meer dan ongeveer zes portfolio-ondernemingen goed worden gevolgd en geassisteerd. Aangezien de gemiddelde bezetting van de limited partnerships neerkomt op drie general partners, beperkt dit aantal ook het aantal portfolioondernemingen van de gemiddelde venture-firma's tot ongeveer 18 ondernemingen;

$b$. de voorbereiding van een portfolio-investering is nauwelijks een financiële aangelegenheid in de gebruikelijke zin. Het is een proces van selectie (in $1981 \mathrm{kreeg}$ de branche 6000 aanvragen, waarvan 900 tot venture-financiering leidden) en van onderhandelen. Het proces is een combinatie van zaken waarbij technische kennis wordt vereist, marktervaring, management-selectie en voldoende inzicht in problemen die moeten worden besproken met accountants, advocaten, industrie-consultants en de belangrijkste afnemers. Per general partner zullen per jaar veelal niet meer dan twee van deze investeringen kunnen worden voorbereid en gerealiseerd. In tabel 6 wordt hier een nadere illustratie van gegeven. 
Voor-onderzoek voor een venture-investering ${ }^{2}$

- Eerste contact met ondernemer, december 1981

Daarna:

- bezoeken aan/van ondernemer $(4 x)$

- gesprekken met drie concurrenten, 5 afnemers, 2 toeleveranciers

- referenties ingewonnen bij voormalige superieuren en collega's van ondernemer. Tevens bij zijn bankiers, accountants en advocaat

- besprekingen met branche-deskundige consultant

Vervolgens:

- advisering terzake van samenstelling management-team

- onderhandelingen over financieringsopzet en aandelenfinanciering door Oxford Partners, het venture-kapitaalfonds onder beheer van Oxford Venture Corporation

- nadere onderhandelingen over koers van aandelen te verwerven door Oxford Partners; aanpassingen als winstprojecties niet worden gehaald; anti-dilution-regeling

- afrondende besprekingen en afsluiting overeenkomst in juni 1982

\section{Rendement}

Het rendement van de venture-kapitaalondernemingen is een graadmeter zowel voor het succes van deze kapitaalverschaffers als voor het succes van de portfolio-ondernemingen waarin zij investeren. Zonder de vermogensappreciatie van deze ondernemingen immers is er geen rendement voor de venture-kapitaalfirma. De meest gezaghebbende Amerikaanse bron voor venture-kapitaalgegevens, Capital Publishing Corporation, komt bij de berekening van het rendement van de venture-branche in de Verenigde Staten op een samengesteld jaärrendement van $26 \%$ voor de periode van 1960 1980 en voor de periode $1975-1980$ op $33 \%$. Deze percentages vertegenwoordigen de rekenrente waartegen de geapprecieerde waarde van de portfolio-investeringen contant wordt gemaakt per datum der oorspronkelijke investering en tot het bedrag dier investering. Ofschoon er uitschieters naar boven zijn, vooral bij venture-ondernemingen met lange ervaring waar jaarrendementen tussen 40 en $50 \%$ niet zelden voorkomen, zijn er uiteraard ook vele afwijkingen van het gemiddelde naar beneden. Het algemene beeld is echter dat het rendement van de Amerikaanse venture-kapitaalbranche gemiddeld $10-15 \%$ ligt boven dat van alternatieve risicomijdende investeringen.

De meest representatieve groep van de venture-branche, die van de onafhankelijke venture-ondernemingen, omvat 180 bedrijven. Van de hen verstrekte venture-fondsbijdragen moet men ongeveer $25 \%$ aftrekken voor in liquide vorm aan te houden kapitaal en voor nog niet gerealiseerde toezeggingen. Dan resteert een totaal aan beheerd vermogen van ca. $\$ 2,9$ mrd., dit is gemiddeld $\$ 16 \mathrm{mln}$. per venture-kapitaalfirma. De firma's die reeds enige jaren met succes hebben geopereerd, zullen in de regel $\$ 20 \mathrm{mln}$. of meer beheren. Uitgaande van dit type geeft tabel 7 het profiel van een karakteristiek rendement-scenario, aangevende tevens de spreiding van de rendementen van een venture-kapitaalonderneming. Daarbij is onderscheid gemaakt tussen investeringen waarbij de venture-financier de lead-manager was en die waarin hij slechts als co-investeerder participeerde. 
Scenario van spreiding der rendementen (in $\mathrm{m} \ln \$$ )

Oorspronkelijke investering

16 portfolio-investeringen

10 lead-investeringen

6 co-investeringen

Marktwaarde na 6 jaar

10 leads van $\$ 1,3 \mathrm{mln}$ per investering

$\begin{array}{lrc}1 & 20 \times & 26,- \\ 2 & 10 \times & 26,- \\ 2 & 5 \times & 13,- \\ 2 & 2 \times & 5,2 \\ 2 & 1 \times & 2,6 \\ 1 & 0 \times & - \\ 6 \text { co-investeringen van } \$ 0,33 \text { min per investering } & \\ 1 & 10 \times & 3,3 \\ 2 & 5 \times & 3,3 \\ 2 & 1 \times & 0,7 \\ 1 & 0 \times & - \\ \text { iquiditeiten }(\$ 5 \text { mln a ruim } 10 \% \text { p.j.) } & \underline{10,-} \\ \text { otaal } & & \underline{90,-}\end{array}$

Rendement

van $\$ 20 \mathrm{mln}$ naar $\$ 90 \mathrm{mln}$ in 6 jaar $=28 \%$ op jaarbasis

De venture-kapitaalfirma zal de vermogensappreciatie moeten kunnen realiseren. Dit is het uiteindelijke doel van het venture-kapitaalfonds dat de venture-firma ten behoeve van de limited partners onder beheer heeft. De enige mogelijkheid daartoe is het weer liquide maken van de portfolioinvesteringen. Dit kan slechts worden verwezenlijkt hetzij doordat de portfolio-onderneming een openbare aandelenemissie plaatst en haar aandelen openbaar kunnen worden verkocht, hetzij doordat de portfolio-onderneming een openbare aandelenemissie plaatst en haar aandelen openbaar kunnen worden verkocht, hetzij doordat een grote onderneming de portfolio-onderneming overneemt. Waar iedere venture-firma dan ook op hoopt is dat de portfolio-investeringen zo snel mogelijk rijp worden voor een openbare emissie. Hierin slaagt men in de Verenigde Staten in het algemeen redelijk wel, in vele succesgevallen zelfs binnen enkele jaren. Een grote rol speelt hierbij de omstandigheid, dat in de Verenigde Staten de over-the-counter markt voor de effectenhandel uitstekend functioneert.

Het is duidelijk dat voor het succes van de venture-kapitaalbranche dit weer liquide maken van de portfolio-investering, de zgn. exit-procedure, van levensbelang is. Met dit aspect zal men in Nederland terdege rekening moeten houden als men de mogelijkheden onderzoekt van een soortgelijke benadering in ons land van het venture-kapitaalproces in de Verenigde Staten. Men kan niet verwachten dat particuliere beleggers en instituten geld willen steken in een Nederlands venture-fonds, wanneer weliswaar de voorwaarden aanwezig zijn voor succesvolle groei van de te financieren portfolio-ondernemingen, maar wanneer niet tevens, en wel reeds ten tijde 
van de investeringsbeslissing, het uitzicht bestaat op een herleefde emissiemarkt, met de daaraan inherente actieve handel zowel op de officiële beurs als op de parallelmarkt.

\section{Samenvatting}

De verschillende hierboven beschreven aspecten van het amerikaanse venture capital kunnen op menig punt tot lering strekken. De belangrijkste punten zouden als volgt kunnen worden samengevat:

a. venture capital heeft macro-economisch een groot positief multipliereffect. Zo leidt de beginfase-financiering uit de jaren 1970-1979 ad in totaal $\$ 1,4$ mrd naar verwachting tot een totale jaaromzet van ca $\$ 90$ mrd aan het eind der jaren tachtig;

$b$. het verschijnsel van venture capital heeft steeds betrekking op een klein begin, in de hoop op grote groei. De begin-investering ligt thans op een gemiddelde van $\$ 1,75 \mathrm{mln}$ en de hoop is steeds, dat deze in ca zes jaren groeit met een factor van ongeveer 4,5 , hetgeen een jaarrendement zou betekenen van $28 \%$. De enkele mammoetfondsen die de laatste jaren zijn gevormd van $\$ 100 \mathrm{mln}$ en meer zullen zich, om het fonds in 2-3 jaar volbelegd te krijgen, moeten richten op grotere, reeds wat gerijpte projecten, en daarmee zullen zij een deel moeten prijsgeven van het typische venture-karakter der financiering, t.w. de actieve begin-begeleiding door de investeerder van de nieuwe onderneming;

c. de venture capital-firma's hebben veelal een venture capital-fonds onder beheer. De partners van deze firma's treden doorgaans op als general partners van die fondsen. Aangezien het aantal partners per venture capital-firma gemiddeld drie is en de 'span of control' per partner 6 ondernemingen, bewegen vele fondsen wat hun grootte betreft zich rond een soort standaardmaat van $3 \times 6 \times \$ 1,75 \mathrm{mln}$ plus het in liquide vorm aan te houden kapitaal (ca $25 \%$ ), d.w.z. rond ca $\$ 35 \mathrm{mln}$. Vóór 1978 lag dit bedrag rond $\$ 25 \mathrm{mln}$;

d. opvallend is de grote rol die de drastische verlaging in 1978 van de capital gains tax heeft gespeeld bij de bijna explosieve groei sindsdien van de venture capital-bedrijfstak in de Verenigde Staten. Van belang is het te constateren dat deze belasting stimulans

(i) uitging naar de aandeelhouders der nieuwe onderneming en niet naar deze onderneming zelf;

(ii) wat haar werking betreft slechts voordeel oplevert als er succes wordt geboekt, dus niet in geval van verlies, en ook alleen pas nadat succes is geboekt, d.w.z. 4 tot 7 jaar na de investering;

$e$. de goede functionering in de Verenigde Staten van een о.T.C.-markt maakt dat de venture capital-investeerder de exit-procedure niet als een probleem behoeft te zien;

$f$. bij alle vergelijkingen met de Verenigde Staten moet men er uiteraard rekening mee houden, dat daar de individuele zelfwerkzaamheid en het winstmotief maatschappelijk een grotere rol spelen dan in ons land. Maar in het continue proces van ons zoeken naar nieuwe maatschappelijke evenwichten is het goed te bedenken, dat de amerikaanse 
bedrijfstak voor venture-kapitaal is voortgekomen uit het particuliere initiatief. In de vorm van financieringssteun aan SBIC's speelde de overheid hierbij een slechts bescheiden rol; haar grootste financiële steun betrof een verlichting van de belastingconsequentie welke verbonden is aan het verhoopte succes der venture-investering.

Tenslotte, één aspect bleef onbesproken, maar het loopt door alle voorgaande beschouwingen heen: zelfs in een zo georganiseerde financiële markt als de Verenigde Staten bleek de wil tot vindingrijke vernieuwing groot genoeg te zijn om op het terrein van vanouds gevestigde financiële instellingen in korte tijd een eigen plaats te veroveren voor een nieuwe deelmarkt, die van venture-kapitaal, bediend door een geheel nieuwe bedrijfstak met eigen financieringsinstrumenten, eigen werkwijzen en een eigen kleine wereld van deskundige general managers.

\section{Noten}

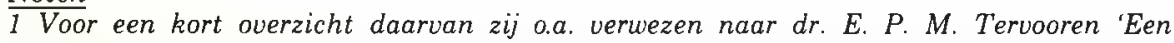
kapitaalmarkt voor jonge ondernemingen. Recente ontwikkelingen in de Verenigde Staten', uitgave Bank, Itec, 's-Gravenhage, januari 1982, blz. 14-16.

2 Voorbeeld verstrekt door Oxford Venture Corporations, Greenwich, Connecticut. 